\title{
Feasibility Analysis For Local Industry Of Gonggong Crackers In Batam
}

\author{
M. Ansyar Bora, Jalius Jama, syahril, Albertus Laurensius Setyabudhi, Ari Susanti
}

\begin{abstract}
This research want to know feasibility for local industry of gonggong crackers in Batam. There is one objective and two hypotheses from this research. The feasibility was reviewed with eight aspect and one of them is financial aspect. This research use questioner and spread to 284 sample from Batam residents. To prove the feasibility in the financial aspect we use payback period (PP), net present velue (NPV), profitability index (PI), and internal rate of return (IRR). The result from this research in financial aspect is feasible. So we suggest to continue this local industry and expand to International Market.
\end{abstract}

Keywords: Local Industri, Feasibility, Gonggong Crackers.

\section{INTRODUCTION}

Batam City is an island that is very strategically located because it is located on an international shipping lane.[1][2] The sea area from Batam reaches $1,035.30 \mathrm{~km}^{2}$. The economic growth of Batam City is higher than some area in Indonesia. That's making Batam become boosting economic growth for the Kepulauan Riau Province. Batam City have a lot of variety of economic sectors which other is communication, electronic, water, oil and gas, banking, shipping, food and beverages, trading and a lot of various other industries.[3] The products from Batam are not sell only in the Batam and Indonesia but also an export commodity for other countries. The existence of this is also in order to increase employment and prosperity. One of economic sector from Batam is Tourism. Our tourist percentage compare with Batam local citizen is high. Tourist from Singapore is $70.67 \%$, and Malay is $114.19 \%$. Batam's tourist also has been from Europe, France, or American. The origin seafood from Batam City is Gonggong. Gonggong is like a snail, and they live in the sea areas in Batam.[4] Everyone like snacks, and almost everyday people consume snacks. Crackers is one of the snacks. [5] So look the high interest to consume snacks, we want to set up local industry which making snacks from gonggong.[6][7] Snack from Gonggong can be used as icon and souvenirs from Batam. Cause there is a lot of tourist from another country.[8][9] Percentage tourist came to Batam from Singapore is $70.67 \%$ and from Malaysia is $114.19 \%$ if compare to local resi-dent who live in Batam (BPS kota Batam 2017). But set up local industry is not a simple business, there is a lot of risk for this business. For minimized the risk from making local industry, we need to know feasibility from this business. So we analysis feasibility from this local industry in this research. This research will be help us to increase possibility profit in this business.[10][11]

\section{METHODOLOGY}

This research use observation method to review market and search total local resident in Batam. Amount local resident in Kepulauan Riau Province at 2017 is 2,082,694 person and $1,236,399$ person stay in Batam City. This population separate to 12 village in Batam. Summary that's population can we see in table 1. We also spread questioner to sample for knowing feedback from customer and customer's need. There is five stage in our research to analyze feasibility this business. First stage is find the idea; second stage is separate questioner; third is making summary from questioner; fourth is tabulation and the last stage is implementation.[12]
Table 1. Total Batam's Population

\begin{tabular}{|ll|}
\hline Village & Citizen \\
Belakang Padang & 19,229 \\
Bulang & 9,924 \\
Galang & 15,723 \\
Sungai Beduk & 86,691 \\
Nongsa & 242,355 \\
Sekupang & 63,133 \\
Lubuk Baja & 243,952 \\
Batu Ampar & 124,165 \\
Batam Kota & 173,479 \\
Sagulung & 86,193 \\
Batu Aji & 65,335 \\
Bengkong & 106,220 \\
Total & $1,236,399$ \\
\hline
\end{tabular}

Analysis financial aspect we use payback period (PP), net present velue (NPV), profitability index $(\mathrm{PI})$, and internal rate of return (IRR). Payback Period (PP) is the length of time required to recover the cost of an investment.

$\mathrm{PP}=($ Cash of project/Investment)/(Annual Cash Inflows) $\times 12$ month

Net Present Value (NPV) is the difference between the present value of cash inflows and the present value of cash outflows over a period of time.

NPV $=($ The expected cash flows $)-($ Invested cash $)$

Profitability Index $(\mathrm{Pl})$ is an index that attempts to identify the relationship between the costs and benefits of a proposed project through the use of a ratio.

$\mathrm{PI}=(\mathrm{PV}$ of Future Cash Flows)/(Initial Investment)

Internal Rate of Return (IRR) is a metric used in capital budgeting to estimate the profitability of potential investments.

IRR $=(P P-1) / P P \times 100 \%$

If result from all calculation is valid, so we can say that in financial aspect this business is feasible. 


\section{RESULt AND Discussion}

\section{A. Questioner}

We need 100 respondent to answer the questioner if we use slovin's formula with $10 \%$ level of confidence. In this research we have 284 respondent, so it's enough for trust result from questioner.

1) Validity and reliability test

Table 1. Validity test

\begin{tabular}{|c|c|c|c|c|}
\hline No & Question & $\begin{array}{c}r_{\text {tubel }} \\
\mathrm{a}=0,05 ; \mathrm{n}=284\end{array}$ & Thitung & remark \\
\hline 1 & P1 & 0,113 & 0.693 & Valid \\
\hline 2 & P2 & 0,113 & 0.658 & Valid \\
\hline 3 & P3 & 0,113 & 0.661 & Valid \\
\hline 4 & P4 & 0,113 & 0.691 & Valid \\
\hline 5 & P5 & 0,113 & 0.687 & Valid \\
\hline 6 & P6 & 0,113 & 0.791 & Valid \\
\hline 7 & P7 & 0,113 & 0.808 & Valid \\
\hline 8 & P8 & 0,113 & 0.793 & Valid \\
\hline 9 & P9 & 0,113 & 0.753 & Valid \\
\hline 10 & P10 & 0,113 & 0.475 & Valid \\
\hline
\end{tabular}

Table 2. Reliability Statistics

\begin{tabular}{|r|r|r|}
$\begin{array}{c}\text { Cronbach's Al- } \\
\text { pha }\end{array}$ & $\begin{array}{c}\text { Cronbach's Al- } \\
\text { pha Based on } \\
\text { Standardized } \\
\text { Items }\end{array}$ & N of Items \\
\hline .768 & .912 & 11 \\
\hline
\end{tabular}

2) Percentage from result questioner

Table 3. Percentage

\begin{tabular}{|c|c|c|c|c|c|c|c|c|}
\hline \multirow{2}{*}{ No } & \multirow{2}{*}{ Poin } & \multicolumn{5}{|c|}{ Percentage } & \multirow{2}{*}{$\begin{array}{c}\text { Poin } \\
1-3 \\
\end{array}$} & \multirow{2}{*}{$\begin{array}{c}\text { Poin } \\
4-5\end{array}$} \\
\hline & & 1 & 2 & 3 & 4 & 5 & & \\
\hline 1 & P1 & 0.3 & 0.4 & 1.95 & 6.7 & 4.85 & 18,7 & 81,3 \\
\hline 2 & $\mathrm{P} 2$ & 0.48 & 1.12 & 4.96 & 9.44 & 6.72 & 28,9 & 71,1 \\
\hline 3 & P3 & 0.4 & 0.72 & 3.92 & 10.64 & 7.04 & 22,2 & 77,8 \\
\hline 4 & $\mathrm{P} 4$ & 1.04 & 1.44 & 4.08 & 9.68 & 6.48 & 28,9 & 71,1 \\
\hline 5 & P5 & 2.08 & 2.08 & 6.08 & 6.32 & 6.16 & 45,1 & 54,9 \\
\hline 6 & P6 & 0.9 & 1.5 & 12.3 & 19.05 & 8.85 & 34,5 & 65,5 \\
\hline 7 & P7 & 0.96 & 1.8 & 12.6 & 10.56 & 8.16 & 45,1 & 54,9 \\
\hline 8 & P8 & 0.84 & 1.68 & 12.36 & 12.12 & 7.08 & 43,7 & 56,3 \\
\hline 9 & $\mathrm{P9}$ & 0.72 & 0.48 & 3.96 & 14.16 & 14.76 & 15,1 & 84,9 \\
\hline 10 & P10 & 2.16 & 2.4 & 10.32 & 14.04 & 5.16 & 43,7 & 56,3 \\
\hline
\end{tabular}

B. Financial aspect analyze

From calculation we have investation in table 3.

Table 4. Investation

\begin{tabular}{|c|c|c|}
\hline No. & Nama & \multicolumn{2}{|c|}{ Investation } \\
\hline 1 & Asset & Rp $2,147,300$ \\
\hline 2 & Variable Cost & Rp $4,838,000$ \\
\hline 3 & Fixed Cost & Rp $3,800,000$ \\
\hline & Total & Rp. $10,938,300$ \\
\hline
\end{tabular}

\section{Depreciation}

All equipment always have depreciation. In this analysis we use straight line depreciation method. From this method we know our depreciation for a month is $\mathrm{Rp} 108,661,-$.

HPP

We calculate HPP with this formula:

HPP=Investation/(Total production output/month)

So HPP from our product is $\mathrm{Rp} 32,555,-/$ pouch, wich one pouch has 500 gram weight.

Analyze

For analyze financial aspect we use four testing from our calculation. Before analyze we must have a decision for price from our product. And this decision we take from questioner. Result from questioner say that Rp 40,000.- for 500 gr weight is cheap. So our decision is $R p 40,000,-/ 500$ gr or $R p 40,000$./pouch. We have profit $R p$ 7,455.-/pouch if our price is $R p$ 40,000.-/pouch. We make 14 pouches each day for the first production. If our entire product sold out so we have profit $\mathrm{Rp}$ $30,018,240 .-$ month. We calculate one month we have 24 workdays. Future value from our profit in the next year is $R p$ $27,289,310$.- if our interest $10 \%$. The result from four testing in analyze financial aspect can see in table 4 .

Table 5. Financial Aspect

\begin{tabular}{|c|l|l|l|l|}
\hline No & \multicolumn{1}{|c|}{ Testing } & \multicolumn{1}{|c|}{ Rules } & \multicolumn{1}{c|}{ calculation } & \multicolumn{1}{c|}{ Result } \\
\hline 1 & $\begin{array}{l}\text { Payback } \\
\text { Periode (PP) }\end{array}$ & $\begin{array}{l}\text { PP }<1 \text { month and } \\
\text { year }\end{array}$ & $\begin{array}{l}\text { 23 days } \approx 5 \\
\text { month }\end{array}$ & Valid \\
\hline 2 & $\begin{array}{l}\text { Net Present } \\
\text { Value (NPV) }\end{array}$ & NPV $>0$ & $\begin{array}{l}\text { Rp } \\
16.351 .010,-\end{array}$ & Valid \\
\hline 3 & $\begin{array}{l}\text { Profitability } \\
\text { Index (PI) }\end{array}$ & PI $>1$ & 1,5 & Valid \\
\hline 4 & $\begin{array}{l}\text { Internal Rate } \\
\text { of Return } \\
\text { (IRR) }\end{array}$ & $\begin{array}{l}\text { IRR } \\
10 \%\end{array}$ & $33 \%$ & Valid \\
\hline
\end{tabular}

\section{CONCLUSION}

The conclusion from this research is

1. Payback period from this business is 5 month which is less than one year, so it is valid.

2. Net present value (NPV) from this business is Rp $16,351,010$.- which is bigger than zero, it's amazing.

3. Profitable Index $(\mathrm{PI})$ from this business is 1.5 bigger than 1 , it's show us that there is profit $50 \%$ greater than our HPP.

4. And Internal Rate of Return from this business is $33 \%$ bigger than normal interest which bank is used. It's show us that profit from this business can pay back bank a loan.

Based on feasibility analysis from Financial Aspect with four parameters from 4 testing we can get conclusion which is this business is feasible. 


\section{REFERENCES}

[1] D. B. Durocher, R. Putnam, and R. Putnamteckcom, "Mining industry process upgrades to reduce energy intensity while improving end product quality," 2013 IEEE Ind. Appl. Soc. Annu. Meet., pp. 1-7, 2013.

[2] W. Cang, Y. Fu, L. Xie, H. Tao, and H. Yang, "Nonlinear Chemical Process Monitoring using Decentralized Kernel Principal Component Analysis and Bayesian Inference *," pp. 1487-1492, 2017.

[3] C. Yang and Y. Pang, "The Application of Wavelet Analysis in Identifying Transformer Magnetizing Inrush Current," 2011 Int. Conf. Electron. Commun. Control, pp. 3988-3991, 2011.

[4] D. B. Durocher, "MINING INDUSTRY Y PROCESS UPGRADES TO REDU CE ENERGY INTENSITY WHIL LE IMPROVING END PRODUCT QUA ALITY tnam," 2013 Work. Power Electron. Power Qual. Appl., pp. 1-7, 2013.

[5] F. Rahimi, S. Member, M. Zhang, B. Hobbs, and S. Member, "Competitive Transmission Path Assessment for Local Market Power Mitigation," pp. 1-8, 2007.

[6] S. Appleton, "And system and," pp. 181-183, 1993.

[7] Z. Da-wei, "Research on the Regional Development Advantage of Green Food Industry in Heilongjiang Province," MSIE 2011, no. 1991, pp. 1104-1106, 2011.

[8] D. Zhou, "Industry Park," 2011 Int. Conf. Bus. Manag. Electron. Inf., vol. 4, pp. 92-95.

[9] J. Yuan and D. Huang, "Completed Hybrid Local Binary Pattern for Texture Classification," 2014 Int. Jt. Conf. Neural Networks, pp. 2050-2057, 2014.

[10] I. Conference, N. Technology, and X. Kunzou, "Exploration on Personnel Training for Regional Game Industry Development," no. Icent, 2010.

[11] T. P. Dong, J. C. Chou, C. L. Hung, and W. Chen, "The Role of Intellectual Capital in Taiwanese Design Industry," 2010 IEEE Int. Conf. Manag. Innov. Technol., pp. 783-787, 2010.

[12] B. zul azmi, B. H. Hayadi, "Design of Expert System to Determine Stock Investment Using Forward Chaining Method," Jour Adv Res. Dyn. Control Syst., vol. 10, pp. 1869-1873, 2018. 